YEARBOOK

of ANTITRUST

and REGULATORY

STUDIES

www.yars.wz.uw.edu.pl
Peer-reviewed scientific periodical, focusing on legal and economic issues of antitrust and regulation. Creative Commons Attribution-No Derivative Works 3.0 Poland License.

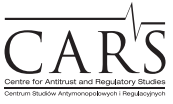

Centre for Antitrust and Regulatory Studies, University of Warsaw, Faculty of Management www.cars.wZ.uw.edu.pl

\title{
The Influence of Economic Theories and Schools on Competition Law in terms of Vertical Agreements
}

\author{
by \\ Zbigniew Jurczyk*
}

\section{CONTENTS}

I. Introduction

II. The scope and effects of the economization of competition law

III. The influence of neoclassical economics

1. Double marginalization model

2. The free riding model

IV. Vertical agreements according to the Harvard School model

V. Vertical agreements according to the Chicago School and Post-Chicago School

VI. Vertical agreements in the Austrian School's competition model

VII. Vertical agreements in ordoliberal economics

VIII. Vertical agreements in the transaction cost theory

IX. Conclusions

\section{Abstract}

The paper aims at showing the influence and the views espoused by economic theories and schools of economics on competition policy embedded in antitrust law and conducted by competition authorities in the field of vertical agreements. The scope of the paper demonstrates how substantially the economization of antitrust law has changed the assessment as to the harmfulness of vertical agreements. The analysis of economic aspects of vertical agreements in antitrust analysis allows one to reveal their pro-competitive effects and benefits, with the consumer being their

* Dr hab. in economics, Associate Professor at WSB University of Wrocław (Poland); e-mail: zbjur@op.pl. Article received: 1 July 2018; accepted: 28 October 2018. 
beneficiary. The basic instrument of the said economization is that antitrust bodies draw on specific economic models and theories that can be employed in their practice. Within the scope of the paper, the author synthesizes the role and influence of those models and schools of economics on the application of competition law in the context of vertical agreements. In presenting, one after another, the theories and schools of economics which used to, or are still dealing with competition policy the author emphasises that in its nature this impact was more or less direct. Some of them remain at the level of general principals and axiology of competition policy, while others, in contrast, delineate concrete evaluation criteria and show how the application of those criteria changes the picture of anti-competitive practices; in other words, why vertical agreements, which in the past used to be considered to restrain competition, are no longer perceived as such. The paper presents the models and recommendations of neoclassical economics, the Harvard School, the Chicago and Post-Chicago School, the ordoliberal school, the Austrian and neoAustrian school as well as the transaction cost theory.

\section{Résumé}

L'article vise à montrer l'influence et les vues véhiculées par les théories économiques et les écoles d'économie sur la politique de la concurrence inscrite dans le droit de la concurrence et menée par les autorités de la concurrence dans le domaine des accords verticaux. La portée de l'article montre que l'économie du droit de la concurrence a considérablement modifié l'évaluation de la nocivité des accords verticaux. Lanalyse des aspects économiques des accords verticaux dans l'analyse antitrust permet de révéler leurs effets et avantages pro concurrentiels, ayant le consommateur comme leur bénéficiaire. L'instrument de base de ladite économisation est que les organismes antitrust font appel à des modèles économiques spécifiques et des théories qui peuvent être utilisés dans leur pratique. Dans le cadre de cet article, l'auteur résume le rôle et l'influence de ces modèles et de ces écoles d'économie sur l'application du droit de la concurrence dans le contexte d'accords verticaux. En présentant, l'un après l'autre, les théories et les écoles de l'économie qui étaient ou sont encore aux prises avec la politique de la concurrence, l'auteur souligne que cet impact était plus ou moins directe. Certains d'entre eux restent au niveau des principes généraux et de l'axiologie de la politique de concurrence, tandis que d'autres, au contraire, définissent des critères d'évaluation concrets et montrent comment leur application modifie le tableau des pratiques anticoncurrentielles; en d'autres termes, l'article évalue pourquoi les accords verticaux, qui dans le passé étaient considérées restreindre la concurrence, ne sont plus perçus comme tels. Larticle présente les modèles et les recommandations de l'économie néoclassique, de la Harvard School, de la Chicago and Post-Chicago School, de l'école ordinaire, de l'école autrichienne et néo-autrichienne, ainsi que de la théorie des coûts de transaction. 
Key words: economization of competition law; vertical agreements; economic efficiency; competition policy models and schools.

JEL: K21, K42, L10, L40.

\section{Introduction}

The competition policy addressing vertical agreements represents a continuous challenge in terms of the extent to which antitrust authorities may carry out administrative intervention into this type of agreements. Vertical agreements cover a very broad range of products and services as well as types of vertical cooperation. In choosing vertical agreements undertakings substitute market transactions for close, long-term vertical contracts or a less specific legal form which is comprised of agreements between businesses operating on two different levels of the market - upstream and downstream. These are broken down into vertical agreements of an upstream type, which arrange cooperation between suppliers of raw material and spare parts and manufacturers of finished products, as well as a downstream type made up of manufacturers of final products and their distributors. However, vertical agreements, in compliance with antitrust law, are not based solely on more or less specific civil contracts. They are also largely an outcome of certain business practices that have been developed, and behaviors of firms that go beyond the rules of civil law. What may constitute the basis for such agreements in light of competition law are regulations, instructions, recommendations and the sharing of economic information.

Economic theories concerned with the issue surrounding vertical agreements consider them mainly from the perspective of deficiencies, involved in the operations of the market mechanism, seeking to remove those deficiencies through the application of one of the available forms within which an economic activity can be organized, with the form being more market-based, or based on a firm, or an intermediate form accompanied by the use of vertical agreements. Vertical agreements represent a hybrid form of business organization, which is a rational alternative in relation to the other two forms. On account of them having possibly an anti-competitive goal or effects, vertical agreements, or to put it more precisely, vertical restraints have become an important area of operation of antitrust authorities, safeguarding the competition model arising from antitrust law.

According to R. Posner, the antitrust policy addressing vertical agreements represents the most pertinent issue which the present day antitrust authorities must face (Posner, 2005, p. 229). This challenge was brought about by the 
rapid economization of competition law. Inculcating into the work of antitrust authorities the principle of referring to economic theory and analysis in their assessment, and not relying solely on the legal interpretation of the prohibitions laid down in antitrust law, had the effect that vertical agreements gradually ceased to be viewed in such a restrictive way, which after all used to be a mandatory practice until the end of the 1980s.

In the process of competition law economization the importance of the well-known in literature theories and schools of economics varies rather significantly. The aim of this paper is to show the role and the extent of the influence exerted by neoclassical economics, the Harvard School, the Chicago and Post-Chicago School, the ordoliberal school, the Austrian economics as well as the transaction cost theory, on the application of competition law with regard to vertical agreements.

\section{The scope and effects of the economization of competition law}

Vertical agreements seen as a hybrid way of organizing business activity encompass a broad range of products and services and types of vertical cooperation. Moreover, they are the preferable and dominant form in which contemporary business functions. The reason why they are the major focus of antitrust authorities is that in restricting economic freedom of weaker partners they simultaneously undermine free competition. A positive aspect in this respect is that vertical agreements increase economic efficiency of both manufacturers and distributors, while being the carrier of consumers' benefits contained in sales-related services that are being expanded by distributors. Hence, had it not been for numerous vertical restraints imposed on distributors, this efficiency would not be possible to achieve. This is exactly the problem which antitrust authorities must face, and which vertical agreements generate, that is, should competition law protect small and medium-sized enterprises, thus safeguarding their economic freedom and free competition, or whether the objective of exercising the law is to assess the behavior of enterprises in terms of their economic efficiency.

The provisions of antitrust law do not divide the prohibited agreements between firms into horizontal and vertical. Pursuant to the provisions, those agreements are prohibited whose aim or effect is to eliminate, restrain or distort competition on the relevant market. Thus, in order to claim that a particular practice restrains competition, it is not necessary to demonstrate that both premises occur simultaneously. In assessing an agreement, its aim becomes the priority, and only when the aim of the agreement concluded is not known, 
the effects are examined, that is, the practicalities (realities) of the agreement. This way of evaluation, which gives priority to the aim of the agreement, where there is no requirement to refer to its effects, may render antitrust analysis as an endeavor that is purely abstract in its nature, being defined on the basis of a grammatical interpretation of the provision and a hypothesis, devised on the basis of this standard, that an anti-competitive behavior is at play. In the decision-making practice, the severability of these premises affords the authorities enforcing antitrust laws much discretion and subjectivity in their assessment as to the unlawfulness of the alleged anti-competitive agreements, which the authorities derive from presumed intentions and not from the impact of these agreements on real competition. This is because such assessment is only possible when the actual market effects are weighed, in other words, when both the negative and positive effects are assessed. What provides a remedy for this discretion and disregard for the reality in the assessment of a particular agreement is a comprehensive economization of competition law.

The economization of competition law consists of resolving antitrust issues defined by competition law through the following:

1. referring to economic theories, models and categories while settling antitrust cases;

2. applying, in an antitrust analysis, tools and methods relevant to economics;

3. investigating real market effects of practices subject to the assessment.

The attention of antitrust authorities is drawn first and foremost by downstream agreements, that is, the distribution segment based on longterm contracts and arrangements, which organize the cooperation between manufacturers and retail distributors under the systems of selective distribution, exclusive distribution or franchising and agency contracts. Among the clauses included in vertical contracts, establishing the aforementioned distribution systems, there are also price and non-price clauses. Those which are contrary to antitrust law restrain intra-brand competition, create artificial barriers to entry, facilitate the conclusion of horizontal agreements. On the list of prohibited practices, for a dozen or so years, there was resale price maintenance - RPM, which is comprised of minimum and maximum prices, recommended and fixed prices. Moreover, on the list with the most important non-price practices one could find agreements whose outcome is the boycott of sales, advertisement and promotion of the competitor's products, bundling, tying, exclusive dealing agreements and most-favored clauses.

Diverse views exist on the benefits and negative implications of vertical agreements. Still, the ever greater role played by economic considerations in antitrust analysis since the 1980s has had the effect that the benefits revealed 
through this analysis proved much bigger than it had been argued in the past and, crucially, they frequently tend to outweigh the negative effects. Consequently, at the current stage of the application of competition law, only a few practices among those mentioned earlier are still viewed as restraining competition, whereby substantial differences are to be discerned between the United States and the European Union in this respect. The most important one consists of the extent to which the essence of those practices is explained through an in-depth economic analysis. While in the United States the rule of reason is preferred, what holds primacy in Europe is still the per se illegality rule, which is, assessing those agreements in terms of whether or not their form and content comply with the hypothesis of the rule of law prohibiting the conclusion of such agreements on account of their aim or effect.

Nevertheless, the economization process of competition law unfolding on both sides of the Atlantic for 30 years has had the effect that today only very few cases involving vertical agreements are a major concern to be tackled by antitrust authorities. These are in the first place arrangements referring to the application of minimum and sticky RPM, location clauses restricting sales markets for distributors, clauses prohibiting or restricting online sales and most-favored clauses (Jurczyk, 2016, pp. 244-353).

\section{The influence of neoclassical economics}

Neoclassical economics did not deal directly with competition policy based on competition law. Still, it is its models that the two schools of economics, which have had the greatest impact on concrete competition policies draw on, namely the Harvard School and the Chicago School. The two most useful models of neoclassical economics will be recalled here: the double marginalization problem and the free-rider problem. These models identify considerable benefits that the vertical integration of firms can yield, which may provide the basis for exempting them from the prohibition on these agreements.

\section{Double marginalization model}

Neoclassical economics is the first one to tackle vertical agreements; it is, however, not in the context of the application of competition law but on account of the reasons which induce businesses to vertical integration and because of the effects this integration has on competition. The double 
marginalization model explains why firms strive for vertical integration. The way the model explains this is that firms seek to reduce the inefficiency which is the outcome of the market power held by firms operating on the upstream or downstream market, or on both markets concurrently. Their market power allows these firms to charge an autonomous mark-up on each of these levels, which, in turn, has the effect that on the market thus structured the mark-up included in the price is charged twice. The inefficiency on such market is especially high when a pure monopoly exists at the level of production and a separate pure monopoly at the level of distribution, that is, in a situation when monopolies operate on the markets which are dependent vertically (two-sided monopolies). This market structure allows each monopoly to set monopolistic prices separately. A monopolistic manufacturer adds its monopolistic mark-up to the costs of production, while a retailer monopolist adds its monopolistic mark-up to the price paid to the manufacturer. In the vertical externality, the market price of the product is then higher than its marginal cost while the sales volume is smaller. Furthermore, aggregated profit is also smaller in relation to the profit which would have been made if the mark-up was to be set jointly and not independently.

Moreover, the phenomenon of double marginalization will disappear when vertical integration takes place following a vertical merger between firms operating on different levels of the market and only one firm is established (one monopoly). The removal of the mentioned inefficiency may also unfold in the form of multi-annual vertical contracts, under which firms agree on setting maximum resale price maintenance and refrain from charging their own mark-up separately. In doing so, they are enabled to maximize their total profit by increasing production and lowering the price. In this setup, as J. Tirol asserts, with reduced market prices and increased production, an integrated industry generates more profit than an non-integrated one (Tirole, 2003, pp. 17-175). This is because integrated firms, while setting a monopolistic trading price, will take into account accordingly the manufacturer's cost of production. The prices following the integration will be lower, which in turn will be to the consumers' advantage. As P. Joskow argues, this is a classic example of the general principle according to which a single monopoly is better than a chain of monopolists. And that is why vertical integration and nonstandard vertical agreements constitute substitutable mechanisms which solve the problem of including profit markup twice in the price (Joskov, 2005, pp. 323-325).

The problem of double marginalization is broader and occurs not only in the setup of a two-sided monopoly, but also in more realistic market conditions when, at both separated levels of the market, monopolistic competition is at play, that is, when firms operating on those markets hold considerable market 
power. Also within such competition, the way to eliminate or reduce double marginalization is provided by vertical integration or a substitutable solution in the form of vertical agreements between firms, as has been demonstrated above. The aim of vertical integration in this kind of a market setup is to avoid double distortion of prices, which occurs when firms add their own price-cost margin at each level of production. Therefore, on the market where at every level of its organization, that is, at the level of production and the level of sales, pure monopolies or entities with considerable market power operate, a single monopoly is better than a chain of independent monopolies.

The economic model of double marginalization was what contributed to the fact that the end of the twentieth century saw antitrust bodies refrain from regarding maximum resale price maintenance as monopolistic prices being entirely prohibited by competition law. The model, however, does not answer the question as to the benefits of minimum and sticky resale price maintenance in vertical agreements. The search for the positive aspects of this kind of prices should, according to some economists, be linked to the producers' interest and their efforts to increase demand, which, however, requires from them the creation of incentives that would prompt retail distributors to make extra investments (Marvel, McCafferty, 1984, pp. 346-359).

\section{The free riding model}

The free riding model formulated by L. Telser is the best known and useful economic model which depicts the benefits to be drawn from sticky and minimum prices in vertical agreements. The model outlines the benefits consumers gain when retailers of a particular product or service, who do not compete on price thanks to minimum resale price maintenance, invest more resources in the development of sales-related services following a higher markup (Font-Galarza, Maier-Rigaud, Figueroa, 2013, p. 4).

The model shows how the minimum RPM set by the organizer of a distribution network eliminate the unfair competition between retail distributors generated by the negative market practice of free riding, while revealing how the same minimum resale price maintenance is conducive to the development of sales-related services provided by distributors and to increased retail sales.

The effect of free riding takes place when those who first and foremost benefit from the seller's effort, aimed at promoting goods, developing presales services and training employees, are rivals who having incurred no additional thus-related costs can offer lower prices than those given by the seller making investments and can therefore attract customers. This 
demonstration of unfair competition brings about negative effects for both the manufacturer and the consumer. In the situation when the free riding effect occurs, no retail distributor will be interested in providing the necessary, from the manufacturer's point of view, level of sales-related services, that is, if the benefits are reaped mainly by the seller who invests neither in the development nor in promotion of those services. The manufacturer, in turn, seeing his sales falling, it being the outcome of the free riders' negative behavior, and in consequence his profits falling, will seek nothing else but to raise retail prices.

According to L. Telser, without setting minimum RPM the varying level of services rendered by distributors will depend on their individual costs and the demand function. Moreover, with minimum RPM the manufacturer can require from his distributors to provide consumers with an optimal level of pre- and post-sales services. Thus, as Telser argues, the minimum RPM is often the best solution for developing intra-brand competition between distributors, with the competition being based on the quality of the commercial services provided to consumers. The minimum price has already a sufficient markup included which makes it possible to finance the development of those services. Creating sales-related services, which provide consumers with new values, will be possible as long as the costs do not exceed the minimum or sticky prices set by the organizer of the distribution network (Telser, 1960, pp. 86-87).

Telser built his model having adopted the hypothesis that current demand depended on a wide range of sales-related services offered by retail distributors. The development of those services, on the other hand, depends on whether distributors can be convinced to bear the costs of additional investments needed for the development of those services. What constitutes an incentive for distributors to bear the additional expenses is the very minimum RPM, which guarantees that distributors will have sufficient revenues to engage in commercial investments. Through the development of sales-related services, the minimum RPM provides consumers with new values, increases the volume of consumer information and thereby increases sales, non-price competition and intensifies inter-brand competition. These positive results arising from the application of minimum resale price maintenance are possible to achieve because it is this resale price maintenance that eliminates the unfair intrabrand competition brought about by a market offence in the form of free riding. That is why in an efficient system of minimum and sticky resale prices, the retail distributor who lowers the price must be aware of the fact that he faces the risk of no longer being delivered goods by the manufacturer. This threat is to encourage distributors to provide an optimal level of services. The assumption that lies behind this arrangement is that when all sellers apply the same prices, which include the cost of the optimal quality services provision, then they are forced to mutual non-price competition. In circumstances when 
minimum or sticky RPM are in force both manufacturers and consumers benefit. L. Telser's model, which provides a rationale for the existence of minimum prices under vertical agreements has, so far failed to be recognized and employed on a bigger scale in the practice of antitrust authorities.

In 2007, the US Supreme Court made a landmark ruling on setting minimum resale prices in vertical agreements in the Leegin case. ${ }^{1}$ It was the first time that the Court stated in its verdict that in assessing minimum resale prices one should abandon the rule of per se illegality and follow the rule of reason, that is, the economic criteria of judgment which make it possible to demonstrate that benefits derived by consumers from minimum resale prices outweigh their costs. By giving this verdict, the Supreme Court clearly showed that Telser's was one of those models which could be used to show the positive effects of minimum RPM for competition and consumers.

Nevertheless, despite the many years that have passed since the Leegin ruling, Telser's model, which justifies the setting of minimum prices in vertical agreements, has so far failed to be recognized and applied more broadly in the practice of antitrust authorities in the United States and the European Union. In the United States, apart from federal antitrust laws, also state regulations apply. It is precisely the states that largely uphold the prohibition on the use of minimum RPM in vertical agreements, contrary to the position of the Supreme Court and the government authorities. The same goes for the EU. The inflexible view of the Member States is derived from the firm stance of the European Commission, which has not changed its attitude developed in the 1970s and 1980s. According to the then jurisprudence, minimum RPM is absolutely contrary to Article 101(1) TFEU on account of its anticompetitive goal (Jurczyk, 2016, pp. 257-268). RPM continues to be seen by the Commission and European courts as hard-core restrictions of competition; this attitude has not been altered by Regulation No 330/210 2 currently in place on the block exemption from the ban on uncompetitive agreements. This is despite the fact that a group of advisors from the Chief Economist Department of the Directorate-General for Competition proposed that RPM be included in the rule of the de minimis market share, which would exempt it from the ban laid down in Article 101(1) TFEU, if the individual share held by the company in the relevant market did not exceed $15 \%$.

\footnotetext{
1 Leegin Creative Lether Prods, v PSKS, Inc, U.S. 877, 2007.

2 Commission Regulation (EU) No 330/2010 of 20 April 2010 on the application of Article 101 (3) of the Treaty on the Functioning of the European Union to categories of vertical agreements and concerted practices. OJ 23.04.210.
} 


\section{Vertical agreements according to the Harvard School model}

The Harvard School built its competition policy model in the 1950s, with E. Mason and J. Bain being its chief originators. The members of the school believed that markets functioned in a defective way and therefore antitrust law was important and should be employed to protect, in the first place, small businesses. In fact, in devising the tenets and objectives of American competition policy, the school summarized and drew conclusions based on the results coming from the activity of government and judiciary antitrust authorities. While creating the theoretical framework for competition policy, the school relied on the structure- conduct-performance paradigm, it being the research focus of the theory of industrial organization. The structural factors include, among other things, the structure of the relevant market, entry barriers, production costs, diversification of products shaping market behavior and practices of firms, which in turn exert influence on market outcomes such as profitability, production volume, pricing, innovations. This paradigm shows that the prime factor which determines the level of market competition for a given industry, and the firms' performance achieved thanks to this competition, is the structure of the market. And vice versa; every firm can impact to some extent its future market position through its performance (Shepherd, 1986, p. 23).

According to Mason, the term 'monopoly' is used as a standard of evaluation and of defining a situation that is against the public interest. Competition, on the other hand, is seen as a situation that is in line with the public interest. By inference, protecting the competitive elements of the market and restraining monopolistic power should be in the public interest, for monopolistic elements such as price discrimination, agreements, predatory prices or dishonest advertising are ubiquitous. Mason also argued that economic analyses of monopolistic situations in competition models were of little use for antitrust law because they could lead to a conflict, since it was not possible to separate the damage suffered by the competitor and the nature of the damage suffered by the public (Mason, 1937, pp. 34-49).

As the Harvard School attributed market structure with key importance, while stressing the firms' economic independence and autonomy which should not be distorted by other stronger competitors' arrangements between firms, including the vertical ones, which may have a negative impact on the market structure, destroying the structure relevant to the functioning of effective competition, creating barriers of entry, or restraining the commercial autonomy of firms linked vertically to a more powerful manufacturer. At the time when the Harvard School used to exert a decisive influence on the way competition 
policy was conducted, many vertical restraints were prosecuted and perceived as a violation of the competition principles laid down in antitrust law. At a time when the principles of antitrust policy devised by the Harvard School were applicable, what was deemed to be unlawful vertical agreements were clauses constituting: tying arrangements prohibiting the distributor from selling within the area of another licensed distributor or opening an additional retail establishment within the area designated to him, prohibiting the sales or promotion of products of competitive firms, as well as all cases of applying resale price maintenance.

What it expected of antitrust laws was to become a guardian of those attributes. Moreover, it saw the causes of market deformation in excessive market power, and the agreements of monopolistic undertakings which, as a result of creating barriers to entry, generating excessive economic concentration, eliminating inconvenient competitors from the market and constraining trade independence of undertakings related vertically with a stronger producer, were destroying the structure appropriate for the functioning of free competition. In the age of the Harvard School, vertical agreements were perceived as reprehensible as cartel agreements.

Throughout the years dominated by the Harvard School, the actions of American antitrust authorities were thus very stringent, while the list of banned practices very long. This is why the impact exerted by the school on the operations of American antitrust bodies within the antitrust doctrine has been met with considerable criticism. This was a time which saw plenty of misconceived proceedings and rulings, both on the abuse of a dominant position and on concluding agreements allegedly restraining competition. Such a victim of the Harvard School doctrine was, among others, the Borden Company, accused by the Federal Trade Commission (FTC) of selling condensed milk of a similar quality to different purchasers at a varying price, although the company's market share was barely $11 \%$. In this case, the FTC took the side of the less effective and smaller milk producers. Although the Commission dropped the charge eventually, the proceeding lasted no less than 10 years until 1967. A misconceived proceeding was also brought against Brown Shoe ${ }^{3}$, a small shoe manufacturer which was forced to resale the franchise stores it had acquired earlier. Despite the benefits to consumers, this transaction was seen as monopolizing the market. The fate of Sylvania company, a small TV set producer, is yet another case in which proceedings were initiated against a company for prohibiting, under its vertical agreement, one of its distributors to open a division in the state where Sylvania had already had a distributor. Sylvania's stubbornness, however, led to its being cleared of all charges by

${ }^{3}$ Brown Shoe Co. v. U.S., 370 U. S. 294. 
the Supreme Court; yet it was not before 1977 when in a landmark verdict the Court finally recognized that this kind of restrictions were admissible in vertical agreements. ${ }^{4}$

Assessed as particularly damaging in the antitrust history was the Alcoa case. In 1939, the Justice Department charged the company with illegal monopolization of the market and demanded that the company be broken up. At the first instance, the District Court accepted the company's line of defense, which argued that the company owed its position to effectiveness and innovativeness, and did not agree to the company's breakup. In 1945, however, this ruling was overturned by the Court of Appeal, which, although admitted that Alcoa was effective, still argued that skills and innovativeness excluded competition, and so effectiveness could not provide legal justification for monopolization. ${ }^{5}$

Another case worth recalling was that of AT\&T, a telecom company. Assessed with hindsight, it was as one of the most misconceived and damaging cases in US antitrust law enforcement. In 1974, the Justice Department, after 18 years of observation, accused AT\&T of abusing its dominant position on the telecommunication market by conducting activities which restrained competition with a view to further monopolizing the market. The claim against the company was that it was precisely to this end that it had been using, among other things, profits from its subsidiary Western Electric, generated on a regulated market, to subsidize the operating costs of its network (cross subsidization) on the non-regulated market. The trial that lasted many years eventually led to a consent decree between AT\&T and the Justice Department in 1982.6 It entailed exempting AT\&T from the ban, in force since 1956, on launching new business activities on the non-regulated market and, in return, the company was to be broken up into 22 regional scattered companies providing local and regional services (Bell operating companies). In January 1984, the monopolist was finally broken up into eight parts. AT\&T could continue providing long-distance telephone services, while the 22 Bocs were consolidated into seven independent regional operators. In 1987, the Court denied Bocs the possibility to provide long-distance services and to manufacture telephone equipment, maintaining that the companies still enjoyed a monopolistic position on the local markets (Pinheiro, 1987, pp. 303-306).

4 Continental Television v. GTE Sylvania, 433 U.S. 361977.

5 U.S. v. Aluminium Company of America, 148 F. 2nd., 1945.

6 U.S. v. AT\&T, 52 F. 131, 1982. 


\section{Vertical agreements according to the Chicago School and Post-Chicago School}

It is important to stress from the outset the difference between the Chicago School and other economic schools and theories in the context of conducting competition policy and enforcing competition law. The difference lies in the fact that its theory and views indicate directly how the state should implement competition policy in practice, how antitrust authorities should interpret and apply antitrust law, and where to look for and how to find and solve antitrust issues. Unlike the Harvard School, in this model of competition policy economics plays the key role.

One of the main premises of the school is that competition in industry, ${ }^{7}$ even if it is a highly concentrated one, functions in a natural way, because of selfregulating and stable forces of industrial markets, provided there are no legal barriers to entry on those markets. Different levels of industry concentration, according to the Chicago School, result from the differences present in the structure of costs, which, in turn, are brought about by economies of scale and innovation, in other words, their source lies in higher efficiency. According to the school's tenets, competition between a few firms may be equally effective as that of a market with many firms.

The greatest and most enduring achievement of the Chicago School is bringing economics into antitrust analysis carried out by competition authorities, and the belief that the only goal of competition law that authorities should follow should be consumer welfare, with the only criterion for assessing the practices described by competition law being economic efficiency. This allows the application of competition law to be more coherent and predictable for businesses.

The Chicago School recommends that the efficiency criterion should be what in the first place guides antitrust bodies in their activities, for it considers the structural measures to be inadequate and ineffective. Hence, the school considers the concentration of firms to be neutral for competition processes, or even pro-competitive. Members of the school also undermined the importance of the durability of barriers to entry for competition processes. As worthy of attention of antitrust bodies, the school recognized only the practices within the scope of setting sticky prices in a cartel and the merger of large firms (Jurczyk, 2012, p. 39). As R. Bork writes, if the practice does not touch upon the issue of production restrictions, one should assume that its goal as well

${ }^{7}$ In competition policy the term 'industry' can be replaced by such terms as: line of business, branch, sector. 
as effect is to create efficiency or some other neutral goal. In this case, the practice should be deemed to be compliant with the law (Bork, 1993, p. 122).

Antitrust bodies should therefore focus their work on eliminating horizontal agreements between monopolistic firms, since in other cases market forces will correct anti-competitive and inefficient market behaviors, thus re-establishing periodically market equilibrium. According to the Chicago School, vertical restraints, which in light of the Harvard School and ordoliberal economics are a thorn in the flesh of competition law and competition policy, not only present no antitrust problems but quite contrary, they manifest the firms' quest for greater economic efficiency and not for advantages through imposing restraints on competition.

Those views are not necessarily fully shared by many members of the so called post-Chicago School who perceive them as too naive, especially one that claims that market forces are capable of removing any deficiencies (Hildebrand, 2002, p. 151). Market deficiencies they see primary in insufficient market information and existing barriers to entry, which considerably restraints and impedes competition processes and, hence, the need for a significantly larger number of interventions on the part of antitrust authorities than that advocated by the Chicago School (Lande, 1994, pp. 631-644). However, they do share the school's view that a great many of vertical agreements previously assessed as anti-competitive, were in fact the result of aiming at higher efficiency, reduced transaction costs or avoiding the free-riding effect. Moreover, what is important is that just like the Chicago School, it recommends that in their proceedings antitrust authorities should not follow the per se prohibition rule while conducting an antitrust analysis of vertical agreements but the rule of reason based on the analysis of economic information, in particular in their assessment of the effects of the vertical practice in question. An arrangement that originally was assessed as anticompetitive in light of the per se rule, may, following further and more detailed analysis, prove that it does not violate competition principles, nor does it make the situation of consumers or suppliers worse - quite the contrary - it may even improve them.

It was thanks to the Chicago and Post-Chicago School that considerable economization of antitrust law could unfold, which has had a major influence on the assessment of vertical agreements over the last 40 years. Even at the end of the 1970s, vertical price and non-price restrictions were considered to be per se illegal. The output of both schools made almost all other vertical agreements, with minor exceptions, namely minimum RPM, legal, or, otherwise, they had to be assessed based on the rule of reason, that is, to examine the market behavior of undertakings from the point of view of their real impact on economic effectiveness. As a result of the antitrust law economization, the US 
Supreme Court gradually began to remedy its mistakes from the past. The ban on using maximum vertical prices, established in 1968 through the Albrecht decision, ${ }^{8}$ was eventually questioned in 1997 in the State Oil Co. ruling. ${ }^{9}$ In its decision, the Supreme Court contended that maximum resale prices arranged between the producer and its authorized dealers should be settled according to the rule of reason. Ten years later, in the aforementioned Leegin ruling, the Supreme Court also questioned the illegality of minimum RPM. Thus, after 96 years the rule of the per se prohibition, applied for the first time with regard to minimum resale prices in the Dr. Miles Medical Co. decision, ${ }^{10}$ ceased to be absolutely mandatory. The Supreme Court's interpretation given in this ruling, which held that the minimum resale prices in vertical trade relationships were unlawful because the manufacturer sought to use those prices to control the operations of distributors and sellers, thus leading to restraining competition among them, was no longer valid.

The economization of competition law triggered by the views espoused by the Chicago School also reached Europe. In the Guidelines on Vertical Restraints, the Commission sees that maximum RPM allow for avoiding double marginalization of profits and that the margin generated through minimum or fixed RPM can enable retailers to provide additional services, and so maximum RPM were deleted from the list of hard-core restrictions. Further to that, it sees the advantages of minimum RPM in combating free riding. The Commission adds, however, that although one can defend all types of restrictions under the law banning monopolistic agreements, the Commission is still skeptical for this defense to also extend to minimum resale prices, since, as it maintains, the negative effects always outweigh the positive ones. ${ }^{11}$ In the similar vein, the CJEU, held, while referring to the Block Exemption Regulation, that this act should not exempt from the ban vertical agreements containing restrictions which are very likely to restrain competition and be to the detriment of consumers. ${ }^{12}$ Thus, at least up to 2022 the economization of competition law in the EU will continue to diverge from the standard for assessing vertical restraints, which is based on consumer welfare, as recommended by the Chicago School.

8 Albrecht v. Herald Co., 390 US 145,1968.

9 State Oil co v. Klhan 522 U.S. 3. 1997.

10 Dr. Miles Medical co. v. John D. Park\&Sons Co., 220 U.S. 373, 1911.

11 Commission notice - Guidelines on Vertical Restraints, OJ 19 May 2010, C 13/1.

12 The Court of Justice decision of 6 December 2017, case file C-230/16, Coty Germany GmbH v. Parfümerie Akzente GmbH, ECLI:EU:C2017:941. 


\section{Vertical agreements in the Austrian School's competition model}

The most important premises and elements of the Chicago School outlined above on the subject of antitrust authorities' work are similar to the views espoused by members of the Austrian School, in particular by F. von Hayek, who argued that government interventions in the area of competition were hostile and worthless. The crucial responsibility of competition policy and antitrust laws should be ensuring the functioning of a free market. Hayek is even more radical on other issues pertaining to the implementation of competition policy itself. It is his view that the government should pass contractual law, commercial law and patent law, as well as laws on protection of industrial property, for which the guiding principle should be competition whatever the circumstances and allowing for no exceptions. In taking on such position, he was against antitrust law in the form adopted by Germany and also against establishing a separate antitrust body with discretionary powers. He believed that the state should confine its role to ensuring proper, clear and always reliable framework for the functioning of a free market without having to continuously intervene into this market (Cox, and Hübner, 1981, p. 30). In referring to the 'hampered market economy', as a negative model of the market economy in relation to the free market economy, L. Mises notes that state interventionism does not confine itself only to preserving the private ownership of the means of production and to protecting it against acts of violence and fraud. Government interventions go much beyond this area in that they force firms to use some portion of their production factors in a way in which they would never have done so, had they had the chance to follow only the dictates of the market (Mrowiec, 2017, pp. 34-35). State interventionism in the form of competition laws and the operations of antitrust authorities is one of those instruments which the Austrian School classifies as elements of a hampered economy. It is therefore rather obvious that a school which prefers free market economy, free of government economic interventionism is adamant in its opposition to an active antitrust policy run by the government and even thinks that such activity is harmful.

Moreover, the new Austrian economics, which refers to the Austrian School in that it assumes that competition (like new classical economics and monetary theory) does not imply a state of affairs arising from the equilibrium existing on a market of perfect competition, but instead sees it as a dynamic process, a tendency, a movement towards an equilibrium, argues that government interventions which go beyond the minimum level of needs merely heighten market imbalance. According to the new Austrian economics, only individual economic freedom and autonomous goals of firms deserve to be protected 
by law. Here, freedom is perceived in two dimensions: as relationships between the state and private undertakings and the freedom between private undertakings themselves (Hildebrand, 2002, p. 157).

Despite the similarities between the Chicago School and the Austrian School as to their understanding of competition, the faith in market forces when solving market and competition problems, and thus a limited range of interventions in the market to be carried out by antitrust authorities, there is a fundamental difference between the schools in terms of the goal of competition policy. For the Chicago School, the sole and exclusive goal of competition policy, and simultaneously a criterion, a standard to be implemented in the practice of antitrust bodies, is consumer welfare, that is, making efficiency-based assessment of market behaviors displayed by firms from the perspective of the application of antitrust law. According to the concept of the Austrian School, on the other hand, what deserves to be protected by law is first and foremost private property and entrepreneurs' full economic autonomy and freedom.

Applying the concept of the Austrian School to the role of competition law, the conclusions drawn from such analysis in terms of vertical agreements are equivocal. On the one hand, this economics regards interventions carried out by antitrust authorities as harmful, for they distort spontaneous market forces set to eliminate any kind of disturbances unfolding in the competition process, with barriers to entry being an exception here as they should be dealt by the state; on the other hand, however, if its goal is to protect economic freedom and autonomy of private firms, in many cases this freedom is restricted under vertical agreements. This is largely the case with firms functioning on the downstream market (of distribution). After all, this type of agreements contains numerous clauses restricting their autonomy, which in light of competition law may be regarded as practices involving vertical restraints. This problem does not exist in antitrust analysis conducted according to the criterion identified by the Chicago School. In assessing these clauses within the framework of the rule of reason, the finding may be that they are actually pro-efficient and to the advantage of consumers.

\section{Vertical agreements in ordoliberal economics}

According to ordoliberal economics, also known as the Freiburg School, established in the 1930s with E. Bohm and W. Eucken as its initiators, an economic order based on competition is what underlies economic welfare and stability. Competition, however, will not be able to fulfill this constructive 
function if it is not given a proper form. The form of competition, which is to allow the economic system to generate those social aims, requires a vital market structure. In the view of ordoliberal economics, what ensures this desired market structure is a perfect competition which should be re-established and maintained (Eucken, 1959, p. 160). In such structure the market power of firms should get dispersed to the greatest possible degree.

Ordoliberal economics is, at this point, in accord with the liberal views that only market economy can ensure social welfare, freedom and justice. Its advocates the believe that in order to realize those aims, what is necessary is to include a stipulation in the constitution that market economy is the basis of the economic system. This legal measure will prevent the distortion and degeneration of competition processes with the results brought about by the market economy being justly distributed across the society, while keeping state intervention into the economy to the minimum (Hildebrand, 2002, 158). Antitrust laws and their enforcement, in line with the ordoliberal thought, should therefore be orientated first and foremost against monopolization of the market and against creating a monopoly, while focusing on controlling the activity of monopolies, cartel agreements and other anti-competitive business arrangements, including vertical agreements. As ordoliberal economics proved to be very influential in Europe in the 1950s, the fact that it regarded vertical agreements as major practices seeking to restrain competition played later a key role in the European Commission's competition policy, distinctive for its being very restrictive and embedded in numerous legal requirements, which was directed against those agreements.

The role of competition law in the ordoliberal concept is to create and control compliance with legal regulations governing competition and to maintain the conditions under which competition can develop (Kohutek, 2012, pp. 58-59). According to W. Eucken, competition devoid of regulations leads to anarchy, and ultimately to self-destruction. Competition constitutes the foundation of the market order, within the framework of a specific legal and ethical system, while placing an emphasis on creating institutional frameworks for the smooth functioning of the market. Competition law is thus vital in preventing the degeneration of competition processes. To this end, the law should ensure that the rules on competition are respected through creating and maintaining the conditions which ensure that competition can function efficiently (Gerber, 1994, p. 50). These conditions include the ability to compete freely, the protection of individual economic freedom and the protection of the competitive structure of the market that is appropriate for perfect (complete) competition.

With respect to its premises, the market structure and the aims and principles involved in conducting competition policy, the Freiburg School 
displays similarities to the Harvard School. The behaviors of firms and market economic outcomes, including consumer benefits, are determined mainly by the market structure, concentration level and barriers to entry, which this school sees as a key problem for the functioning of competition. Both schools recognize that the goals of competition policy are manifold, while the government should remain active in this field. The approach espoused by the ordoliberal school in its evaluation of vertical agreements, just like that by the Harvard School, is therefore very restrictive. Thus, according to ordoliberal economics, many restrictions and obligations imposed under vertical contracts on firms operating on the downward market run counter to economic freedom, the autonomy of undertakings and the principles of perfect competition, and if so, they have to be regarded as reprehensible and competition restraining. The views of ordoliberal economics as to the enforcement of competition law, and the role to be played by antitrust authorities, have had a crucial impact on the shape of competition policy in terms of vertical agreements and also regarding other areas of the policy conducted by the European Commission, and by inference, the Member States. Firms which concluded such agreements believing that such arrangements had neither an anti-competitive objective nor effect, in order to obtain legal certainty in this respect had to notify them to the Commission. Only after having investigated the case in question did the Commission issue either a decision or a clearance when it proved that the conditions required for being exempted from the prohibition laid down in Union law were satisfied (Jurczyk, 2012, pp. 201-210). It was only in 2004 that this legal procedure, which referred directly to the pre-war provisions governing German cartel law, imposing on businesses the obligation to register cartel agreements, was completely abandoned.

The ideas of ordoliberal economics on the principles of conducting EU competition policy continue to be respected by the Commission, which is visible also in the aspect of vertical agreements. Not only does the Commission defend competition as the fundament of the single market functioning, but it also seeks to protect competition by protecting undertakings. In terms of vertical agreements, this is demonstrated by treating minimum RPM as hard core restrictions, as well as by having rejected the proposal of the Chief Economist of Directorate-General for Competition calling for exempting all vertical agreements, including price agreements, from the ban on vertical agreements when the market share of an undertaking does not exceed $15 \%$. 


\section{Vertical agreements in the transaction cost theory}

In the theory of transaction costs, the basic analytical unit in the research on economic organization is transaction and its costs. As such the theory highlights in a particular way the studies on management in a situation when transactions are removed from the market and are placed under unified governance, that is, when changes in ownership take place, as well as changes in terms of incentives and governance structures (Williamson, 1998, pp. 395-396). In other words, when in place of market transactions a hierarchical organization (a firm) is established as being more efficient in eliminating transaction costs related to the conclusion and implementation of contracts, search for market information and opportunism. Moreover, the transaction cost economics emphasizes that the size of the firm, through the absorption of market transactions, cannot grow indefinitely, for the process of supplanting the market is accompanied by an increase in transaction costs arising from coordination and management. In literature these costs are sometimes broken down into transaction market costs, managerial and public costs (Staniek, 2005, p. 25). K. Arrow, who has been credited with introducing the concept of transaction costs, associated those costs with the costs involved in the functioning of an economic system, perceived as a separate type of costs in relation to production costs, them being the focus of neoclassical analysis (Willimason, 1998, pp. 22 and 32). H. Demsetz's definition is more narrowed down, rendering the essence of transaction costs in that he defines them as the exchange of property rights (Demsetz, 1968, p. 35). Transaction costs - in these economists' views - hinder, and in some particular situations block market information. Here the fundamental thought appears that of Hayek, to be further elaborated by Coase, that the market does not operate free of charge. This author believes that the flaws of the market result from transaction costs, which K. Arrow compared to the friction in physical systems. $\mathrm{K}$. Arrow argued, however, that given that 'market failure is not absolute; it is better to consider a broader category that is of transaction costs, which in general impede and in particular cases completely block the formation of markets' (Arrow, 1969, pp. 48-49). Transaction costs - as it is believed - can also hinder an efficient reallocation of resources, if certain transactions have failed to be carried out (Colomo, 2012, p. 545).

The costs of market operation arise largely from searching for information concerned with the investigation of price relationships. The second type of costs involved in market transactions are those pertaining to contract conclusion. They are made up of costs incurred while finding a contractor, negotiating contract terms and conditions (prices, delivery times and payments, delivery 
insurance, contractual penalties) and the costs of resolving disputes arising under the contract. The third type of costs of market operation mentioned by transaction cost economics stems from market uncertainty, as a variable constantly present in different segments of the market. This uncertainty comes from price fluctuations and changes, insufficient knowledge of the behavior of competitors, contractors and consumers, as well as the asymmetry of the information held by market participants. This third type of transaction costs encompasses costs which one could refer to as the costs of contract implementation (Cooter and Ulen, 2012, p. 88).

Improvement of economic efficiency, which economics boils down to economizing on market operation costs, is where the focus of transaction cost economics is centered. Transaction costs should be economized by 'assigning transactions (which differ in their attributes) to governance structures (the adaptive capacities and associated costs of which differ)' (Williamson, 1998, pp. 31-32). This cost saving is thus located within the field of product exchange and governance, and consists of the formation of market structures that are more hierarchical and integrated. The behaviors and decisions aimed at economizing on costs have to lead to supplanting the market exchange with structures and mechanisms proper for a firm. The structures of economic organization which display a greater degree of hierarchy and integration lower the costs, in that they reduce or eliminate uncertainty and opportunistic behavior of distributors and suppliers. These non-market modes of economic organization, perceived as an alternative for economizing on transaction costs, may therefore unfold through restraining effective competition and monopolizing the market, in other words, through supplanting the market by the structure of firms.

In the process of internalization, that is, conducting the mentioned transactions within a single firm, the hazards involved in the market disappear. Next to these borderline modes of organization, one can, however, encounter also intermediate modes (mixed) which are not fully hierarchical and where integration between supplier and buyer is embedded in contracts containing clauses which limit, to a greater or lesser degree, the autonomy of suppliers supplying materials and sellers of products provided to end-users. These agreements lower economic uncertainty and transaction costs in relation to vertical cooperation based on market transactions. These are the self-same agreements which underpin the operation of selective distribution networks and franchising, which are so dominant in today's sales of technically complex products, branded and valuable products to end-users. Thus, economizing on transaction costs can unfold at the price of competition deterioration. It is in such circumstances that competition policy intersects with transaction cost economics. While assessing agreements which bring about such effects, 
transaction costs saving could provide the reason and rationale behind having them exempted from the prohibition on restrictive agreements.

In traditional competition policy, any kind of subject-based and territorial restrictions included in vertical agreements were regarded as anti-competitive practices. Transaction cost economics took a different view on those restraints. It assumed that those practices were aimed at protecting transactions and thereby reducing transaction costs. Declining transaction costs are one of the potential benefits that vertical integration may yield. ${ }^{13}$

There is no doubt that the emergence of transaction cost economics has allowed antitrust analysis of vertical agreements to be expanded towards their assessment being carried out more on the basis of the rule of reason than that of per se illegality, that is, to weigh the effects arising from restraining competition and the benefits arising from reduced costs and increased efficiency, of which a considerable portion should also be enjoyed by consumers. Therefore, in the context of the transaction cost theory, many restrictive clauses included in vertical agreements such as exclusive dealing, exclusive distribution, resale price maintenance, tying, bundling are no longer seen and assessed solely in terms of market monopolization (that is, price arrangements, barriers to entry, discrimination) on account of their possible cost savings.

With respect to employing directly transaction cost economics in competition policy and law, the costs calculation presents certainly a hindrance. Nevertheless, it should not prevent the perception of vertical restraints, as proposed by transaction cost economics, where those restraints are perceived as seeking to eliminate uncertainty, counteracting opportunism and economizing on costs, to be considered and taken into account in the antitrust analysis conducted by competition authorities. At the same time, this assertion ought to be complemented in that references to transaction costs made in specific cases by American or EU competition authorities are rather theoretical and intuitive, without drawing on empirical evidence. Savings generated within those costs are mentioned as positive effects, which are to compensate for competition restraints arising under agreement that, however, are not directly associated with a specific type of transaction costs. This statement can be found in the Commission Regulation for the application of Article 101(3) of the Treaty to categories of vertical agreements and concerted practices, in which, for example, it was laid down that certain vertical agreements can be exempted from the prohibition if they can lead to a reduction in the transaction and distribution costs of the parties. ${ }^{14}$

13 Guidelines on the assessment of non- horizontal mergers under the Council Regulation on the control of concentrations between undertakings, OJ C 2008, 256/6.

${ }^{14}$ Commission Regulation of 20 April 2010 for the application of Article 101 (3) of the Treaty to categories of vertical agreements and concerted practices OJ L 102/2010. 
Notwithstanding the foregoing, competition policy became, in terms of vertical agreements, one of the areas where the achievements of transaction cost economics can be applied in practice. That is so because the majority of endeavors seeking to economize on transactions costs concentrate on distribution. Consequently, transaction costs, as an analytical tool in antitrust cases, also undermined the negative effects of leveraging (Williamson, p. 33), which is to monopolize a related market not yet monopolized, as well as they provide new arguments in support of viewing vertical prices as never anticompetitive in their effects. This position - as H. Hovenkamp writes - places the theory of transaction costs somewhere in the middle, although slightly closer to Chicago's position than that espoused by the Harvard School (structural), which has always displayed a hostile attitude towards leveraging, and the traditional leverage theory (Hovenkamp, 2010, p. 8).

The American and EU antitrust authorities incorporated relatively early the transaction cost economics into their competition policy as a further useful tool in an economic analysis assessing the restrictions included in vertical agreements. With respect to the United States, the first decision on vertical agreements in which a reference to the concept of transaction costs is made concerns the already mentioned Supreme Court verdict in the GTE-Sylvania case. That the views of transaction cost economics were taken into consideration by the court can be found in the Court's statement that 'vertical restrictions of various forms have been widely used in our free market economy.' Moreover, a clear reference to transaction cost savings can be encountered in the reasons given for the verdict by the Supreme Court in the Broadcast Music, Inc. case. Applying the rule of reason, the Supreme Court discerned benefits in the vertical agreements which it examined in the reduced number of individual transactions and easier access to the base of the songs concerned. ${ }^{15}$

Microsoft also cited transaction costs when seeking to justify its sale to PC producers of a Windows 98 and Internet Explorer bundle. In its defense against the charge that the company in this way, using its market power held on the operating systems' market, aimed at building a strong monopolistic position also on the web browser market, Microsoft argued that this kind of sale could provide end users with value in that by buying products in a bundle they would incur reduced transaction costs and avoid other inconveniencies. However, the argument citing transaction costs was accepted neither by the US Justice Department nor by the District Court, ${ }^{16}$ to which this high-profile antitrust case went.

15 Verdict in Broadcast Music, Inc v. Columbia Broadcasting System, Inc 441 U.S. 1 (1979).

16 U.S. v. Microsoft Corp., 87 F. Supp.2d30 (D.D.C. 2000) and U.S. v Microsoft Corp., F 3.d 34, 56 (D.C. Cir. 2001). 
In its decision-making practice, the Commission also invokes transaction cost savings as an argument for the agreement concerned not to fall within the prohibition of Article 101(1) TFEU. At this point, one could mention four Commission decisions where transaction costs were a valid criterion in the assessment of a particular agreement according to the legal rules laid down in this Article. ${ }^{17}$ The best known Commission decision is one made in the UEFA Champions League case. In the decision, the Commission contended that failing to conclude the agreement on selling jointly the rights to broadcast the Champions League matches, TV operators interested in buying those rights would have to incur considerably higher transaction costs. The fourth decision pertains to the quantitative distribution system of Land Rover motor vehicles, which the EU antitrust authorities examined as a result of Land Rover refusing to authorize Auto 24 SARL as a distributor of this brand of motor vehicles. In the Auto 24 SARL verdict, the Court of Justice, referring, among other things, to the transaction cost rank in distribution systems adopted the following stance: 'Vertical agreements falling within the categories defined in this Regulation ${ }^{18}$ can improve economic efficiency within a chain of production or distribution by facilitating better coordination between the participating undertakings. In particular, they can lead to a reduction in the transaction and distribution costs of the parties and to an optimization of their sales and investment levels.' 19

In evaluating the relevance of the transaction cost analysis for antitrust cases, one should, however, note that it is not a practice that is frequently applied by the European and US competition authorities.

\section{Conclusions}

Integration efforts of businesses, both those which incorporate previously independent firms and those consisting of specific long-term contracts, are dictated by efficiency goals based on the benefits to be derived from scale, scope, synergy effects arising from the same research and development

17 Commission Decision of 5 February 1992, 92/204 IV/31.572 and 32.571 - Building/the Netherlands, 1992, OJ L 92/1; Commission Decision of 8 October 82002 COMP/C2-/38.014 - IFPI Simulcasting 2003. OJ L 107/58; Commission Decision of 23 July 2003 COMP/C.2 - 37.398 - UEFA Champions League, 2003, OJ L29/25.

18 The Regulation cited refers to Commission Regulation (EC) No 1400/2002 of 21 July 2002 on the application of the Article 81(3) of the Treaty to categories of vertical agreements and concerted practices in the motor vehicle sector.

19 Court of Justice judgment of 14 June 2012, file case C-158/11 Auto 24 SARL v. Jaguar Land Rover France SAS. 
center, development and implementation of common and uniform marketing programme for advertisement, promotion and pricing policy, or using the same know-how. In vertical integration, the source of synergy is the reduction of transaction costs arising from the opportunism of contractors operating independently and from thus-related risk. The effects of synergy, the efficiency, will also be brought about by specialization, when, for example, the manufacturer acquires control of a specialized entity within the scope of distribution and marketing.

The aforementioned efficiency considerations, looking for ways to economize on transaction costs, as well as consumer benefits derived from vertical agreements, demonstrated because of the progressing economization of antitrust law, have had the effect that today vertical agreements are largely assessed according to the rule of reason, in other words, according to how they will impact the market and consumers, rather than according to the per se illegality rule, which is an assessment carried out from the point of view of the aim of the agreement, with the rule being strictly applied in horizontal agreements and particularly in cartel agreements.

The discussion conducted in the paper shows that in their ponderings the salient schools of antitrust policy, such as Harvard, Chicago and ordoliberal, neglected the factors exerting influence on the functioning of efficient competition and further to that, while providing the grounds for their assessment of antitrust cases that involved vertical agreements, they neglected the achievements of the transaction cost theory, despite it being available at the time. The schools remained faithful to efficiency understood and described by neoclassical economics, failing to include directly transaction cost economics in their discussion on the manifestations of efficiency. As H. Hovenkamp notes, in the model of 'free riding' (Hovenkamp, 2010, p. 7) devised by L. Telser, one can see clearly the interface between the Chicago School and transaction cost theory when it comes to vertical agreements. The explanations as to the efficiency of the application of resale price maintenance presented in the model are essentially a form of transaction cost analysis. As Hovenkamp maintains, although Telser did not use Coase's theory for his basis, his famous paper on RPM refers to alternative costs, mechanisms allowing distributors to provide additional services. To illustrate the point, Telser asserted that a firm could choose between its own distribution and a distribution through independent firms, depending on the cost relation between those choices (Telser, 1960, pp. 86-87). The manufacturer could try to use contractual provisions to require that optimal services be provided by the distributor, however, monitoring and the distributor's costs thus related could render this solution unattractive. That is why the resale price mechanism is often the best option allowing distributors to compete between one another 
through launching new services as long as their costs do not affect the resale price maintenance (Telser, 1960, p. 90).

In evaluating the impact of economic theories and schools presented herein on competition law applied with respect to vertical agreements, one should note that although the views on the harmfulness of vertical agreements to the functioning of efficient competition are quite differentiated in the theory of economics, they still share a common idea. Economics and economic analysis as regards the application and enforcement of competition law by antitrust authorities should play a key role, with some of those theories, as the Austrian School, going as far as to consider competition law to be false or even harmful and therefore leaving competition matters exclusively to economics. The economization process of competition law started by the Chicago School, despite the opportunism of antitrust authorities, is thus still ongoing. With respect to vertical agreements, as indicated in the paper, the process reduced significantly the catalogue of vertical practices and clauses supposedly restricting and being contrary to the rules of competition law. Although if one were to take into consideration the international universalism and international coherence of competition policy and competition law, as well as antitrust cases, then the economization process (which is for antitrust authorities to be guided by economic efficiency in their evaluation process of vertical agreements) is more visible in the practice of American rather than EU antitrust bodies, and ultimately in the practice of the Member States.

\section{Literature}

Arrow, K. J. (1969). The Organization of Economic Activity: Issues Pertinent to the Choice of Market versus Non-Market Allocations. Joint Economic Committee of Congress, Washington DC.

Bork, R.H. (1993). The Antitrust Paradox, New York.

Colomo, P.I. (2012). Market Failure, Transaction Costs and Article 101 (1) TFUE Case Law, European Law Review, October, no 5.

Commission notice - Guidelines on Vertical Restraints, OJ 19 May 2010, C 13/1.

Commission Regulation (EU) No 330/2010 of 20 April 2010 on the application of Article 101 (3) of the Treaty on Functioning of the European Union to categories of vertical agreements and concerted practices, OJ 23.42010.

Cox, H. and Hübner, H. (1981). Wettbewerb. Eine Einführung in die Wettbewerbstheorie und Wettbewerbspolitik. In: Cox, H., Jens, U. and Markert, K. (eds), Handbuch des Wettbewerbs, München.

Cooter, R. and Ulen, T. (2012). Law \& Economics, New York.

Demsetz, H. (1968). The cost of transacting. Quarterly Journal of Economics, February, no 82. 
Eucken, W. (1959). Die Grundsätz der Wirtschaftspolitik, Hamburg.

Font-Galarza, A., Maier-Rigaud, F.P. and Figueroa, P. (2013). RPM Under EU Competition Law: Some Considerations from a Business and Economic Perspective, Competition Policy International, November (1).

Gerber, D.J. (1994). Constitutionalizing the Economy: German Neo-liberalism, Competition Law and the „New” Europe, American Journal of Comparative Law, vol 42.

Hildebrand, D. (2002). The Role of Economic Analysis in the EC Competition Rules. London, New York.

Hovenkamp, H.J. (2010) Harvard, Chicago, and Transaction Cost Economics in Antitrust Analysis, University of Iowa Legal Studies Research Paper, no 10-35, December.

Guidelines on the assessment of non- horizontal mergers under the Council Regulation on the control of concentrations between undertakings, OJ C 2008, 256/6.

Joskow, P.L. (2005). Vertical Integration. In: Ménard, C. and Shirley, M.M. (eds), Handbook of New Institutional Economics, Berlin, Heidelberg.

Jurczyk, Z. (2012). Kartele w polityce konkurencji Unii Europejskiej, Warszawa.

Jurczyk, Z. (2016). Co dalej z minimalnymi cenami odsprzedaży? In: Fornalczyk, A. and Skoczny, T. (eds) Ekonomia ochrony konkurencji. Ograniczenia wertykalne. Warszawa.

Kohutek, K. (2012). Praktyki wykluczające przedsiębiorstw dominujących. Prawidtowość $i$ stosowalność regut prawa konkurencji, Warszawa.

Lande, R.H (1994). Beyond Chicago: Will Activist Antitrust Arise Again? Antitrust Bulletin, vol. 39.

Marvel, H.P. and McCafferty, S.H. (1984). Resale Price Maintenance and Quality Certification. Rand Journal of Economics, vol. 15.

Mason, E.S. (1937). Monopoly in Law and Economics, Yale Law Journal, vol. 47(1).

Mrowiec, M. (2017). Austriacka Szkoła Ekonomii, Warszawa.

Pinheiro, J. (1987). AT\&T Divestiture \& the Telecommunications Market. Berkeley Technology Law Journal, Vol. 2, September.

Posner, R. (2005). Vertical Restraints and Antitrust Policy. University of Chicago Law Review; winter, no 72.

Shepherd, W.G. (1986). The Twilight of Antitrust. Antitrust Law and Economic Review, vol. 18.

Staniek, Z. (2005), Uwarunkowania i wyznaczniki efektywności systemu instytucjonalnego. In: Pacho, W. (ed), Szkice ze wspótczesnej teorii ekonomii, Warszawa.

Telser, L. (1960). Why Should Manufactures Want Fair Trade? Journal Law and Economics, no 3.

Tirole, J. (2003). The Theory of Industrial Organization, Cambridge, Massachusetts, London. Williamson, O.E (1998). Ekonomiczne instytucje kapitalizmu, Warszawa. 